\title{
LOCUIREA ÎN CONTEXTUL STĂRII DE URGENTĬ/
} HOUSING UNDER THE STATE OF EMERGENCY

\author{
Miruna MOLDOVAN*, drd. arh./ PhD. stud. arch. \\ Dana Gabriela GîTA**, sociolog/sociologist
} moldovanmiruna2@yahoo.com

*Universitatea Tehnică din Cluj-Napoca, RO/The Technical University of Cluj-Napoca, RO

* Universitatea Babeș-Bolyai, Cluj-Napoca, RO/ Babeș-Bolyai University, Cluj-Napoca, RO

\begin{abstract}
Rezumat
Dacă arhitectura este cadru de desfășurare a vieții cotidiene, prezentul studiu va analiza cum răspunde aceasta în fața unei crize. Situația excepțională a pandemiei și a stării de urgență instituită pe teritoriul României face necesară repunerea în discuție a arhitecturii de urgență. Într-o astfel de situație, ne întrebăm dacă arhitectura nu capătă un rol terapeutic și dacă locuința - prin funcțiunea ei nouă de spațiu de izolare - nu devine chiar un instrument de limitare a răspândirii unei epidemii. Mai mult decât atât, o astfel de situație de criză are la rândul ei un impact semnificativ asupra vieții sociale a omului și influențează cu precădere modul
\end{abstract}

\begin{abstract}
If architecture is a framework for everyday life, this study will analyse how it responds to a crisis. The exceptional situation of the pandemic and of the state of emergency established on the Romanian territory makes it necessary to question the emergency architecture. In such a situation, we ask ourselves if architecture does not acquire a therapeutic role and if the home - through its new function of isolation space - does not even become a tool to limit the spread of an epidemic. Moreover, such a crisis situation in turn has a significant impact on human social life and mainly influences the way of housing. And the way of housing influences
\end{abstract}


de locuire. lar modul de locuire influențează rutina și stilul de viață al fiecăruia. Prin urmare, prin cercetarea de față ne propunem să discutăm problematica locuirii de urgență (în centrul de carantină) și cea a locuirii în urgență (în autoizolare la domiciliu) și dorim să analizăm, pe baza răspunsurilor unui chestionar sociologic efectuat pe perioada stării de urgență, cum influențează situația de criză viața cotidiană și cum poate arhitectura media impactul situației menționate.

\section{Cuvinte cheie/ Keywords}

locuire, stare de urgență, arhitectură de urgență, rutină, viață socială/

housing, state of emergency, emergency architecture, routine, social life

\section{Răspunsul arhitecturii la criza pandemiei}

De-a lungul istoriei, omenirea a avut de-a face cu numeroase situații de criză care au determinat evoluția diferitelor abordări în arhitectură, precum și apariția unor noi paradigme în domeniul locuirii. O situație de criză particulară este pandemia. De cele mai multe ori, în urma unei pandemii, arhitectura a fost regândită și rediscutată din rațiuni sanitare. Autorul Geoff Manaugh care studiază arhitectura carantinei, spunea într-un interviu pe tema pandemiei de coronaviroză că „trebuie să ne întoarcem la acest răspuns spațial medieval pentru a controla pandemia, răspuns care presupune ca arhitectura și urbanismul să devină instrumente medicale" (2020).

Totodată, pentru a combate efectele unei epidemii și pentru a limita răspândirea unei boli, la nivel everyone's routine and lifestyle. Therefore, through this research we aim to discuss the issue of emergency housing (in the quarantine centre) and housing in emergency (self-isolation at home) and based on the answers of a sociological questionnaire conducted during the state of emergency, we want to analyse how does the crisis situation influence the quality of daily life.

\section{Architecture's response to the pandemic crisis}

Throughout history, mankind has had to deal with numerous crisis situations that have determined the evolution of different approaches in architecture, as well as the emergence of new paradigms in the field of housing. A particular crisis situation is the pandemic. Most of the time, following a pandemic, the architecture was rethought and re-discussed for health reasons. Author Geoff Manaugh, who studies quarantine architecture, said in an interview on the coronavirus pandemic that "we need to return to this medieval spatial response in order to control the pandemic, which requires architecture and urbanism to become medical tools" (2020).

At the same time, in order to combat the effects of an epidemic and to limit the spread of a disease 
global, instituirea stării de urgență este o măsură general valabilă, ce implică numeroase restricții și limitări pentru populație menite să protejeze sănătatea acesteia. Spre exemplu, în ceea ce privește România, starea de urgență a fost declarată prin decret prezidențial în contextul pandemiei de coronaviroză (Decret nr. 195/16.03.2020) și a durat timp de șaizeci de zile. Starea de urgență a presupus o serie de măsuri legale care au limitat deplasările locuitorilor, au mizat pe distanțare socială ca instrument principal de limitare a răspândirii infectărilor și au presupus necesitatea izolării la domiciliu sau impunerea carantinei instituționalizate pentru persoanele infectate (Ordonanța $\mathrm{nr}$. 1/17.03.2020). Toate aceste măsuri legale, precum și vulnerabilitatea în fața bolii și un anumit grad de responsabilizare al locuitorilor, au făcut ca marea majoritate a populației să petreacă tot mai mult timp în locuința personală.

Atunci când discutăm despre arhitectură, răspunsul imediat al acesteia la o situație de criză îl constituie arhitectura de urgență. Când discutăm despre pandemie, răspunsul este unul medical și presupune crearea unor locuințe pentru cei aflați în izolare sau carantină, dar și a unor dotări sanitare temporare care să suplimenteze centrele de tratament ale bolii respective.

În general, locuirea de urgență presupune răspunsul arhitecturii la nevoile de adăpostire și securitate ale oamenilor care și-au pierdut locuințele personale în circumstanțe extraordinare. În cazul de față, măsura de carantinare necesară limitării răspândirii bolii presupune ca locuirea de urgență să fie parte a centrului de carantină. Pe lângă aceasta, autoritățile au impus măsura de izolare voluntară la domiciliu, care a fost implementată de marea majoritate a globally, the establishment of a state of emergency is a generally valid measure which involves numerous restrictions and limitations for the population meant to protect its health. For example, regarding Romania, the state of emergency was declared by a presidential decree in the context of the coronavirus pandemic (Decree no. 195/16.03.2020) and lasted for sixty days. The state of emergency involved a series of legal measures that limited the movement of residents, relied on social distancing as the main tool to limit the spread of infections and involved the need for isolation at home or the imposition of institutionalized quarantine for the infected persons (Ordinance No. $1 / 17.03$.2020). All these legal measures, as well as the vulnerability to the disease and a certain degree of responsibility of the residents, have made the vast majority of the population to spend more and more time in their personal homes.

When we talk about architecture, its immediate response to a crisis situation is the emergency architecture. When we talk about the pandemic, the answer is a medical one and it involves the creation of housing for those in isolation or quarantine, and also temporary health facilities to supplement the treatment centres of the respective disease.

In general, emergency housing implies an architecture's response to the housing and security needs of the people who have lost their homes in extraordinary circumstances. In the present case, the quarantine measure necessary to limit the spread of the disease presupposes that the emergency housing is part of the quarantine centre. In addition, the authorities imposed the measure of voluntary isolation at home, which was 
locuitorilor și care presupune un caz particular al locuirii în urgență. Vom discuta pe larg atât locuirea de urgență, cât și locuirea în urgență.

În ceea ce privește dotările sanitare, în marile centre urbane unele spitale au fost transformate în centre de tratament destinate exclusiv pacienților afectați de epidemie. Mai mult decât atât, unele centre de tratament temporare au ocupat alte clădiri cum ar fi săli polivalente și stadioane, iar altele au fost ridicate de la zero în apropierea facilităților medicale existente.

În România, în cazul pandemiei de coronaviroză, centrele de tratament au fost instituite fie în clădiri aparținând Spitalelor Clinice de Boli Infecțioase sau Spitalelor Generale din municipii, fie în clădiri multifuncționale de tip sportiv. În Cluj-Napoca, județul Cluj, Sala Polivalentă „BT Arena” a devenit centru temporar de suport medical covid-19 cu o capacitate de 358 de paturi pentru pacienții cu forme de infectare ușoare și medii. (Instituția Prefectului Județului Cluj, 2020). Configurația spațială a sălii polivalente a permis mobilarea terenului de sport interior cu paturi de spital separate prin panouri mobile ușoare realizate din carton (fig. 1). Cu toate acestea, separarea nu este totală, pacienții sunt cu toții în același spațiu. Sala polivalentă este un obiect de arhitectură menit să aducă oamenii împreună, devenind un loc pentru apropiere și interacțiune socială. În această situație însă, sala polivalentă devine un loc pentru izolare, iar prin noua amenajare, un spațiu care trebuie să asigure distanțare între pacienți, precum și între pacienți și cadre medicale. implemented by the vast majority of residents and which involves a particular case of housing in emergency. We will discuss in detail both emergency housing and housing in emergency.

In terms of health facilities, in large urban centres some hospitals have been transformed into treatment centres intended exclusively for patients affected by the epidemic. Moreover, some temporary treatment centres occupied other buildings such as sports halls and stadiums, and others were raised from scratch near existing medical facilities.

In Romania, in the case of the coronavirus pandemic, the treatment centres were set up either in buildings belonging to the Clinical Hospitals of Infectious Diseases or General Hospitals in the municipalities, or in multifunctional sports buildings. In ClujNapoca, Cluj County, the "BT Arena" Sports Hall has become a temporary covid-19 medical support centre with a capacity of 358 beds for patients with mild and moderate forms of infection. (Institution of the Prefect of Cluj County, 2020). The spatial configuration of the sports hall allowed the furnishing of the indoor sports field with hospital beds separated by light movable panels made of cardboard (fig. 1). However, it is not a complete separation, the patients are all in the same space. The Sports Hall is an architectural object meant to bring people together, becoming a place for closeness and social interaction. In this situation, however, the sports hall becomes a place for isolation, and through the new arrangement, a space that must ensure distance between patients, as well as between patients and medical staff. 


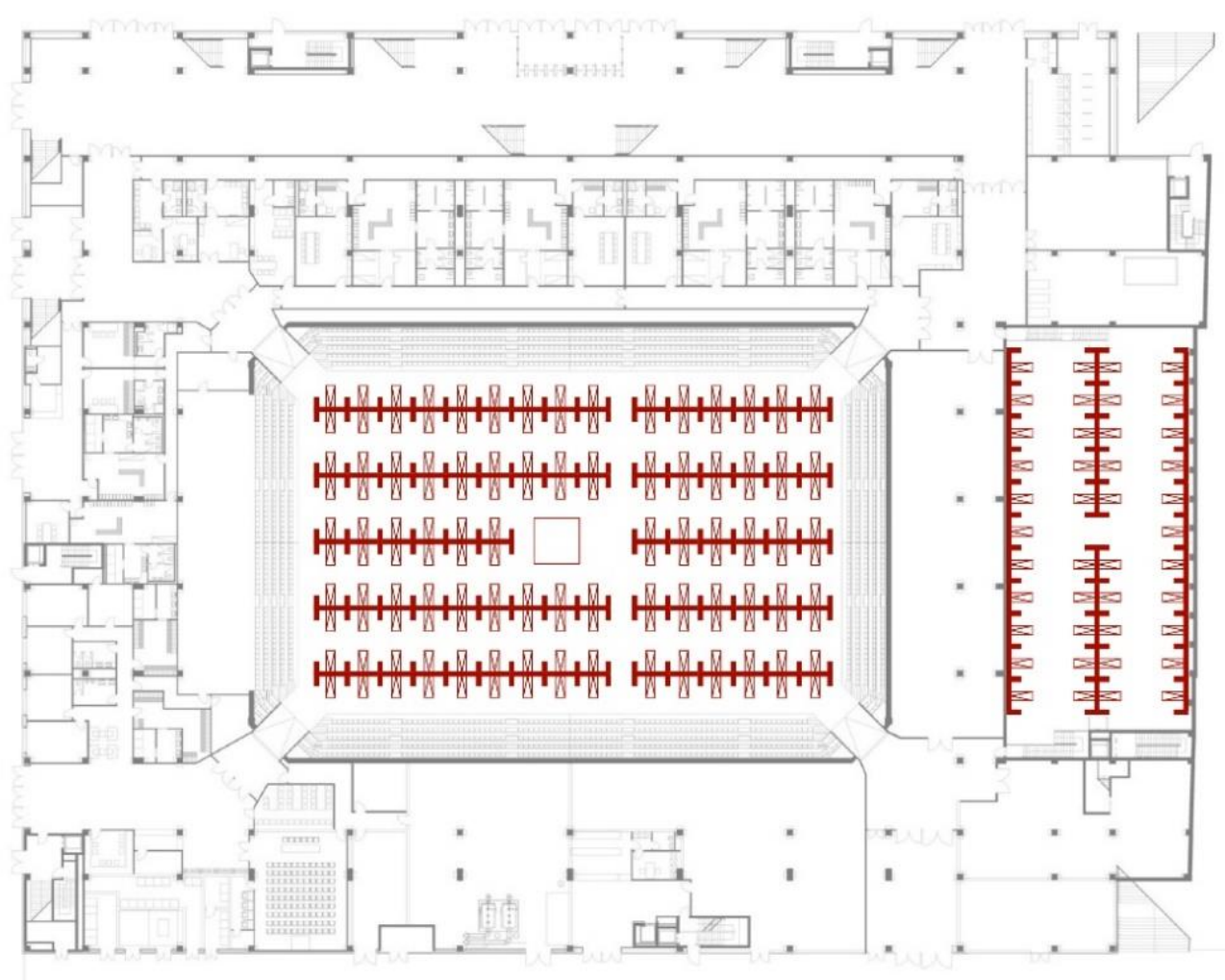

Fig. 1. Schema de amenajare a sălii polivalente „BT Arena” în centru de tratament. Sursa: autorii (după fotografii de la fața locului de Raed Krishan și după planul sălii conform dicositiganas.ro)/

The development of "BT Arena" Sports Hall into a treatment centre plan. Source: authors (after photos taken from the site by Raed Krishan and according to the hall plan on dicositiganas.ro)

În municipiul Constanța, județul Constanța, Armata Română a construit un Spital Modular de Izolare și Tratament pe terenul stadionului de fotbal "Portul” (Ministerul Apărării Naționale, 2020). În București, tot Armata Română a construit Spitalul Militar ROL 2, pe care I-a instalat în apropierea Institutului de
In Constanța, Constanta County, the Romanian Army built a Modular Isolation and Treatment Hospital on the field of the "Portul" football stadium (Ministry of National Defence, 2020). In Bucharest, the Romanian Army also built the ROL 2 Military Hospital, which was installed near the "Ana Aslan" 
Gerontologie și Geriatrie „Ana Aslan” din Otopeni, județul Ilfov (Ministerul Apărării Naționale, 2020a). Aceste două tipuri de centre de tratament temporare au fost alcătuite din corturi medicale și containere metalice, cuprinzând „printre altele, unități de triaj, laborator, radiologie, sterilizare, zonă de decontaminare" (Ministerul Apărării Naționale, 2020b). Pe de altă parte, a existat inclusiv un spital temporar proiectat și construit de organizația nonguvernamentală „Dăruiește Viață” prin donații și sponsorizări private. (Asociația Dăruiește Viață, 2020) Spitalul Modular Elias 1 cu o capacitate de 50 de paturi, era destinat tratării bolnavilor în stare gravă din cauza coronavirusului și a fost amplasat în curtea Spitalului Elias din Bucuresti. Toate cele trei centre de tratament temporare mentionate au fost ridicate din elemente prefabricate modulare (containere metalice și corturi gonflabile), fixate pe structuri ușoare demontabile. Acest tip de structură permite asamblarea și montarea într-un timp scurt, fiind adaptabile diferitelor amplasamente. Spre deosebire de centrul de tratament amenajat în sala polivalentă, în aceste spitale modulare izolarea pacienților este totală (un singur pacient având propriul container închis). Cu toate acestea, costurile de realizare sunt mai ridicate, iar timpul de implementare mai îndelungat: în acest caz avem dea face cu edificarea completă a unei structuri noi, pe când în cazul sălii polivalente, avem de-a face doar cu amenajarea unei structuri existente.

Prin urmare, arhitectura sanitară în pandemie presupune în primul rând utilizarea structurilor spitalicești existente, dar și implementarea imediată a unor soluții universale temporare și modulare (cortul și containerul). Implementarea acestor soluții a venit atât din partea puterii statale, cât și din partea societății civice, prin implicarea directă a
Institute of Gerontology and Geriatrics in Otopeni, Ilfov County (Ministry of National Defence, 2020a). These two types of temporary treatment centres consisted of medical tents and metal containers, including "among others, sorting units, laboratory, radiology, sterilization, decontamination area" (Ministry of National Defence, 2020b). On the other hand, there was also a temporary hospital designed and built by the non-governmental organization "Give Life" ("Dăruiește Viață") through donations and private sponsorships. (Give Life Association, 2020) Modular Hospital Elias 1, with a capacity of 50 beds, was intended for the treatment of patients in serious condition due to coronavirus and was located in the courtyard of Elias Hospital in Bucharest. All three temporary treatment centres mentioned were built from modular prefabricated elements (metal containers and inflatable tents) fixed on light removable structures. This type of structure allows a short time assembly and installation, being adaptable to different locations. Unlike the treatment centre arranged in the sports hall, in these modular hospitals there is a complete isolation of patients (every patient has his own closed container). However, the construction costs are higher and the implementation time is longer: in this case we are dealing with the complete construction of a new structure, while in the case of the sports hall, we are dealing only with the arrangement of an existing structure.

Therefore, the sanitary architecture in a pandemic involves first of all the use of existing hospital structures, but also the immediate implementation of temporary and modular universal solutions (tent and container). The implementation of these solutions came from both state power and civic society, through direct involvement of non- 
organizațiilor nonguvernamentale și a cetățenilor. Putem afirma că în această situație, arhitectura de urgență este cadru pentru izolare și tratament, iar implementarea ei a fost posibilă datorită interacțiunilor public - privat și administrație comunitate. Dar odată cu arhitectura sanitară și locuirea primește funcția medicală de izolare. Vom analiza în continuare cum afectează acest aspect calitatea vieții locuitorilor și ce rol joacă arhitectura în acest proces.

\section{Locuirea de urgență}

După cum menționam anterior, în contextul pandemiei, una din măsurile necesare pentru a limita răspândirea bolii face ca persoanele suspecte de infectare să fie nevoite să intre în carantină instituționalizată. Măsura de carantinare presupune locuirea pe o perioadă limitată de timp într-un spațiu impus, care să asigure satisfacerea nevoilor de bază și care să asigure acțiunile de supraveghere și control, atât al bolii, cât și al persoanei respective (Ordin nr. 313/26.02.2020).

Carantina presupune o situație excepțională în care persoana afectată devine (mai) vulnerabilă. Întrebarea pe care ne-o punem prin acest studiu este dacă poate arhitectura să fie cea care să medieze acest impact social. Spațiul pus la dispoziție de instituțiile statului pentru carantină devine locuință de urgență, iar locuința de urgență devine parte a centrului de carantină. Autoritățile sunt cele care asigură acoperirea nevoilor de bază a persoanei carantinate, cele care se ocupă de repartizarea și supravegherea acesteia în centrul de carantină și cele care dețin controlul asupra siguranței și securității acesteia. Prin urmare, putem spune că în locuirea de urgență în centrul de carantină, din governmental organizations and citizens. We can state that in this situation, the emergency architecture is a framework for isolation and treatment, and its implementation was possible due to public-private and administration-community interactions. But alongside sanitary architecture the housing also receives the medical function of isolation. We will further analyse how this aspect affects the quality of life of residents and what role does architecture play in this process.

\section{Emergency housing}

As mentioned earlier, in the context of the pandemic, one of the necessary measures for limiting the spread of the disease is to force people suspected of being infected into institutionalized quarantine. The quarantine measure involves living for a limited period of time in an imposed space, which ensures the satisfaction of basic needs and the surveillance and control actions of both of the disease and the person concerned (Order no. 313 / 26.02 .2020).

Quarantine implies an exceptional situation in which the affected person becomes (more) vulnerable. The question we ask ourselves through this study is whether the architecture can be the one to mediate this social impact. The quarantine space provided by state institutions becomes an emergency housing, and emergency housing becomes part of the quarantine centre. The authorities are the ones who ensure the coverage of the quarantined person's basic needs, who are in charge of the person's distribution and supervision in the quarantine centre and those who have control over their safety and security. Therefore, we can say that in the emergency housing inside the quarantine centre, 
locuitor, omul devine utilizator. Individul ca utilizator nu decide nimic, el doar folosește spațiul în condițiile în care îi sunt oferite și se află în relație directă de subordonare cu autoritățile.

Centrul de carantină ca obiect de arhitectură în sine nu mai există astăzi. Cu toate acestea, clădiri destinate în totalitate carantinei au fost construite de-a lungul istoriei. Una dintre primele astfel de clădiri era lazaretul (din italianul lazzaretto), apărut în secolul al XV-lea și care lua forma fie a unei nave ancorate la mal, fie a unei clădiri închise propriu-zis amplasată pe o insulă sau la marginea orașului și care era destinată carantinării marinarilor care se întorceau în comunitățile lor din zone de risc (Cassar, 1987: 369). Mai apoi, de-a lungul timpului, datorită evoluției tehnologiei și a inovațiilor din domeniul sănătății, carantina a început să pară o idee învechită pentru tratarea bolilor și s-a constatat că nu este fezabilă construirea și întreținerea unei clădiri pentru carantină, pentru că ar urma să fie goală și neutilizată. Centrele de carantină din trecut, inclusiv lazaretele, au fost transformate în alte funcțiuni pentru sănătate sau în hoteluri și muzee (de exemplu Lazzaretto Vecchio din Veneția funcțional în secolele XV-XVII, astăzi muzeu și atracție turistică). Astăzi, după cum menționam la începutul studiului, pare că revenim la metoda medievală de gestionare a epidemiilor și pare că este nevoie din nou de centre de carantină care să răspundă nevoii de izolare și protecție, atât a celui carantinat, cât și a comunității din jur. Așadar, are loc din nou o transformare în arhitectură: clădiri existente cu funcțiuni diverse devin centre de carantină pentru o perioadă limitată de timp. from an inhabitant a person becomes a user. The individual as a user does not decide anything, he only uses the space in the conditions in which they are offered and is in a direct relationship of subordination with the authorities.

The quarantine centre as an architectural object in itself no longer exists today. However, buildings destined entirely for quarantine have been built throughout history. One of the first such buildings was the lazaretto (from the Italian lazzaretto), which appeared in the 15th century and took the form of either a ship anchored on the shore or an actualclosed building located on an island or on the outskirts of the city which was intended to quarantine sailors returning to their communities from risk areas (Cassar, 1987: 369). Then, over time, due to the evolution of technology and healthcare innovations, quarantine began to seem as an outdated idea for the treatment of diseases and it was found that it is not feasible to build and maintain a quarantine building, because it would become empty and unused. The quarantine centres of the past, including the lazarettos, have been transformed into other healthcare functions or hotels and museums (for example the Lazzaretto Vecchio in Venice functional in the XV-XVII centuries, today a museum and tourist attraction). Today, as we mentioned at the beginning of the study, it seems that we are returning to the medieval method of managing epidemics and it seems that quarantine centres are needed again to meet the need for isolation and protection, both for the quarantined and the surrounding community. Therefore, a transformation in architecture is taking place again: existing buildings with various functions become quarantine centres for a limited period of time. 
Poate că cel mai adecvat program de arhitectură care să preia funcția de centru de carantină ar fi putut fi imobilul de locuințe de necesitate. Conform legislației în vigoare, locuințele de necesitate se finanțează și se realizează de către Statul Român în condițiile stabilite pentru locuința socială și se închiriază temporar persoanelor și familiilor ale căror locuințe au devenit inutilizabile din cauza unor diferite situații de criză. (Lege nr. 114/1996). Însă în România, nevoia proiectării și construirii acestor tipuri de locuințe a fost și este în continuare amânată sau ignorată de autoritățile statului și astfel, în contextul stării de urgență disponibilitatea acestor tipuri de locuințe s-a dovedit a fi inexistentă. Din acest motiv, la nivelul județului Cluj de exemplu, centrele de carantină s-au instituit în clădiri pentru sănătate sau în clădiri private pentru turism și pentru culte.

Din categoria clădirilor pentru turism, hotelurile și motelurile au fost cele preluate și controlate de autoritățile administrației locale (în acest caz de Instituția Prefectului Județului Cluj) pentru instituirea centrelor de carantină. Au fost preluate atât hoteluri urbane (Hotelul Univers T sau Grand Hotel Napoca), cât și hoteluri și moteluri izolate cu destinație turistică (Hotel Alpin din comuna Băișoara sau Motel Montana din orașul Huedin). Atât hotelul, cât și motelul, au ca elemente funcționale principale recepția, cazarea și alimentația publică. În centrul de carantină, recepția devine spațiu de triere și repartizare, iar camerele de cazare devin locuințe de urgență.

Putem porni de la ideea că locuința de urgență este în primul rând un adăpost temporar. În acest caz, datorită standardelor confortului hotelier, locuința
Perhaps the most appropriate architectural program to take over the function of a quarantine centre could have been the necessity social housing (ro: locuinta de necesitate). According to the legislation in force, the necessity social housing is financed and built by the Romanian State under the conditions established for social housing and is temporarily rented to individuals and families whose housing has become unusable due to various crisis situations. (Law no. 114/1996). However in Romania the need to design and build these types of homes has been and is still postponed or ignored by state authorities and thus, in the context of the state of emergency, the availability of these types of homes has proven to be non-existent. For this reason, in Cluj County, for example, the quarantine centres have been set up in healthcare buildings or in private buildings destined for tourism and worship.

From the category of buildings destined for tourism, hotels and motels were those taken over and controlled by the local administration authorities (in this case by the Institution of the Prefect of Cluj County) for the establishment of quarantine centres. Both urban hotels (Hotel Univers T or Grand Hotel Napoca) and isolated hotels and motels with tourist destination (Hotel Alpin in Băișoara commune or Motel Montana in Huedin city) were taken over. Both the hotel and the motel have reception, accommodation and public catering as their main functional elements. In the quarantine centre, the reception becomes a space for sorting and distribution, and the accommodation rooms become emergency homes.

We can start with the idea that the emergency home is primarily a temporary shelter. In this case, due to the standards of hotel comfort, the emergency 
de urgență oferă mai mult decât strictul necesar al adăpostului. Atenția acordată esteticii amenajării interioare și design-ului unei camere de hotel, precum și suprafața generoasă a încăperii pot avea o influență pozitivă asupra locuirii în carantină. Prin chestionarul sociologic realizat pentru a fundamenta cercetarea de față (care se va detalia în a doua parte a studiului) s-au primit și răspunsuri legate de locuirea în carantină. Din acestea reiese că, prin calitățile spațiale interioare și prin dotările specifice, arhitectura turistică a putut media implicațiile statutului de utilizator al persoanei aflate în carantină și i-a putut ameliora condițiile de viață vulnerabile din perioada de criză: „Nu avem voie să ieșim din cameră sau să interacționăm, dar avem condiții bune, televizor și wi-fi care ne ajută să comunicăm cu cei de acasă" (răspuns liber primit prin chestionarul sociologic).

Apoi, centrele de carantină s-au instituit în clădiri pentru sănătate precum spitalele și clinicile (Spitalul de Boli Infecțioase sau Clinica de Medicina Muncii din Cluj-Napoca). Aceste clădiri au fost primele transformate datorită accesibilității și posibilității de testare sau tratare a bolnavilor. Camera de spitalizare sau salonul devine camera de carantină. Caratinarea presupune o formă de locuire și nu neapărat de tratament. în acest caz însă, utilizatorul devine, vrând-nevrând, pacientul, iar controlul autorităților asupra persoanei carantinate se poate simți mult mai prezent. Spre deosebire de camera de hotel, amenajarea interioară a unui salon este pur funcțională, dotările sunt minimale și acoperă strictul necesar, iar spațiul alocat fiecăruia este mult mai limitat. Aici, calitatea locuirii este reductibilă la funcțional și sanitar, putând avea o influență negativă asupra desfășurării vieții în carantină. Pe home offers more than the bare necessities of the shelter. Attention to the aesthetics of the interior design and design of a hotel room, as well as the generous surface of the room can have a positive influence on quarantined housing. Through the sociological questionnaire made to substantiate the present research (which will be detailed in the second part of the study), answers related to housing in quarantine were also received. It shows that, through the interior spatial qualities and specific endowments, the tourist architecture was able to mediate the implications of the quarantined person's user status and was able to improve their vulnerable living conditions during the crisis: "We are not allowed to leave the room or to interact, but we have good living conditions, TV and Wi-Fi that help us communicate with those at home" (free answer received through the sociological questionnaire)

Afterwards, quarantine centres were set up in health buildings such as hospitals and clinics (Infectious Diseases Hospital or Occupational Medicine Clinic in Cluj-Napoca). These buildings were the first to be transformed due to their accessibility and the possibility of testing or treating the sick. The hospital room or ward becomes the quarantine room. The quarantine involves a form of habitation and not necessarily treatment. In this case, however, the user becomes, willingly or not, the patient, and the control of the authorities over the quarantined person can be felt much more present. Unlike the hotel room, the interior design of a hospital ward is purely functional, the facilities are minimal and cover what is strictly necessary, and the space allocated to each person is much more limited. Here, the quality of housing is reducible to functional and sanitary, and can have a negative 
de-altă parte, datorită asocierii salonului cu tratamentul sau cu vindecarea, poate exista percepția de ocrotire mai puternică decât în cazul camerei de hotel, care poate din nou, media relația om - locuință de urgență.

Nu în ultimul rând, tot în județul Cluj, Arhiepiscopia Ortodoxă a Clujului a pus la dispoziția autorităților locale șaptezeci de locuri de cazare în Mănăstirea Piatra Craiului, devenind astfel centru de carantină (Ivanov, 2020). În mănăstire, chilia a devenit spațiu pentru locuirea de urgență. Locuirea monahală în sine presupune izolare, cumpătare și o înclinație către viața spirituală. Spre deosebire de salon sau de camera de hotel, amenajarea interioară a unei chilii este dominată de austeritate, de absența confortului fizic, fiind doar un cadru neutru al vieții monahale. Izolarea într-un astfel de centru de carantină a unei persoane străină acestui tip de viață poate fi mult mai șocantă decât în cazul primelor două situații discutate și poate avea un impact social mult mai pregnant. Și în acest caz controlul administrației asupra utilizatorului se poate simți mai puternic, însă pe de altă parte acest fapt poate restabili siguranța locuitorului.

Putem observa că locuirea de urgență în centrele de carantină diferă în primul rând datorită funcțiunii inițiale a clădirii (fig. 2). În toate cele trei cazuri se face remarcată relația celui carantinat cu administrația responsabilă de calitatea vieții pe perioada izolării. În studiile sale de antropologie a locuirii, Vintilă Mihăilescu afirma că „dacă locuința poate fi identitară, pierderea ei poate fi mortală." (2020: 45). În situația carantinării, omul nu își pierde neapărat locuința personală, însă este dislocat și forțat să locuiască pe o perioadă de timp în condiții influence on the development of life in quarantine. On the other hand, due to the association of the ward with treatment or healing, there may be a stronger perception of protection than in the case of the hotel room, which may again mediate the human-emergency housing relationship.

Last but not least, in Cluj County, for example, the Orthodox Archdiocese of Cluj provided the local authorities with seventy accommodation places in the Piatra Craiului Monastery, thus becoming a quarantine centre (Ivanov, 2020). In the monastery, the cell became a space for emergency living. Monastic living in itself presupposes isolation, temperance, and an inclination toward the spiritual life. Unlike the hospital ward or the hotel room, the interior design of a cell is dominated by austerity, the absence of physical comfort, being only a neutral framework of monastic life. The isolation in such a quarantine centre of a person foreign to this type of life can be much more shocking than in the case of the first two situations discussed and can have a much greater social impact. In this case, too, the control of the administration over the user may feel stronger, but on the other hand this fact can restore the safety of the resident.

We can see that emergency housing in quarantine centres differs primarily due to the initial function of the building (fig 2). In all three cases, the relationship of the quarantined person with the administration responsible for the quality of life during the isolation period is noted. In his studies on the anthropology of housing, Vintilă Mihăilescu stated that "if the house can become an identity, its loss can be fatal." (2020: 45). In the case of quarantine, the person does not necessarily lose his personal home, but is displaced and forced to live for a period of time in 
extraordinare într-un loc străin. Rutina îi este întreruptă subit, iar echilibrul cotidian este destabilizat. Tocmai din acest motiv, putem afirma că funcția socială a locuirii de urgență presupune mai mult decât un adăpost, ea putând fi sau trebuind să fie un loc sau un mijloc de restabilire a sigurantei și echilibrului în urma unei crize. Prin urmare, în cazul locuirii de urgență în centrul de carantină, relația om - administrație ar putea fi un factor cheie care să contribuie la această restabilire și chiar la asigurarea ocrotirii în situația neobișnuită cu care se confruntă omul. extraordinary conditions in a foreign place. Their routine is abruptly interrupted and their daily balance is destabilized. Precisely for this reason, we can say that the social function of emergency housing involves more than a shelter, it can be or should be a place or a means of restoring security and balance in a crisis. Therefore, in the case of emergency housing in a quarantine centre, the human-administration relationship could be a key factor contributing to the recovery and even to ensuring protection in the unusual situation which the human being is facing.
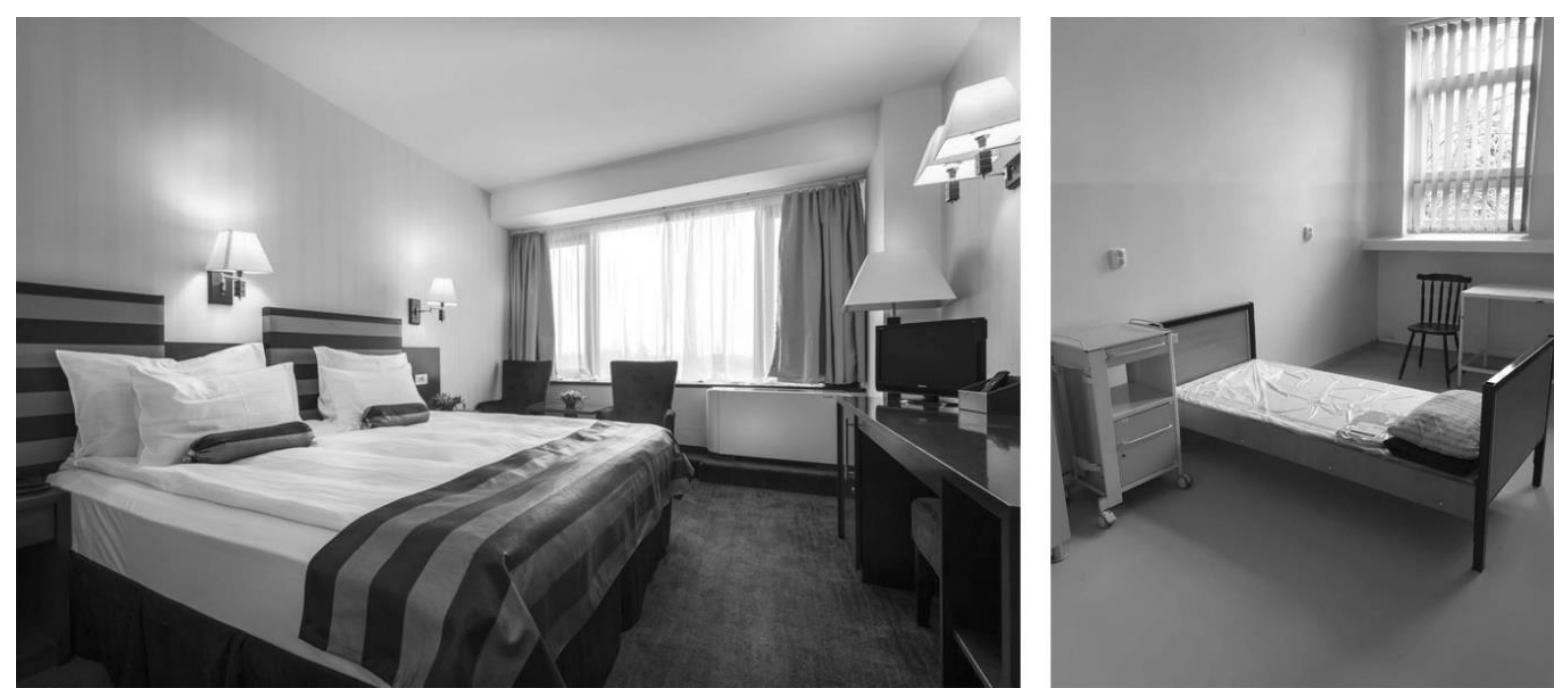

Fig. 2. Locuire în carantină în Hotel Napoca (stânga) vs. Locuire în carantină în Spitalul de Boli Infecțioase Cluj-Napoca (dreapta). Sursa: actualdecluj.ro/

Housing in quarantine in Hotel Napoca (left) vs. Housing in quarantine

in Infectious Diseases Hospital in Cluj-Napoca (right). Source: actualdecluj.ro 
După cum am menționat anterior, amenajarea interioară și dotările prestabilite ale spațiilor au putut influența pozitiv sau negativ locuirea de urgență și au fost de cele mai multe ori reductibile la minimal, acoperind doar strictul necesar. Deși vulnerabilă, perioada de locuire în carantină este scurtă. După această perioadă însă, omul revine în locuința personală în autoizolare. Tocmai din acest motiv cercetarea de față se va concentra mai mult pe implicațiile situației în care izolarea are loc la domiciliu. Prin comparație, locuința personală presupune familiaritate, o amenajare interioară personalizată, precum și dotări care de cele mai multe ori devin maximale.

\section{Locuirea în urgență}

Dacă în cazul carantinei, timpul de izolare era în medie de paisprezece zile, autoizolarea a făcut ca timp de cel puțin șaizeci de zile (perioada reglementată a stării de urgență) desfășurarea vieții de zi cu zi să aibă loc în mare parte în locuința personală. Urgența este o situație de tulburare a cotidianului, iar aceste măsuri drastice pe care a trebuit să și le însușească omul au generat un impact social asupra vieții sale obișnuite, influențând calitatea acesteia. Dacă în cazul carantinării am discutat despre locuirea de urgență, în cazul autoizolării vom discuta despre locuirea în urgență.

Într-un interviu despre „cum construim acasă”, arhitectul Iulia Stanciu afirma că „probabil prima lecție a unei arhitecturi care să lucreze pentru calitatea locuirii este pentru o înțelegere sensibilă și atentă a locurilor, a ipostazelor, pentru că de locuit, locuim în toate ipostazele vieții noastre." (2020). Dar cum locuim într-o ipostază de urgență? Cum poate
As previously mentioned, the interior design and the pre-established facilities of the spaces could positively or negatively influence emergency housing and were often minimized, covering only what is strictly necessary. Although vulnerable, the quarantine period is short. After this period, however, humans return to their personal home in self-isolation. It is for this reason that the present research will focus more on the implications of the situation in which isolation takes place at home. By comparison, the personal home involves familiarity, a personalized interior design, as well as facilities that often become maximized.

\section{Housing in emergency}

If in the case of the quarantine, the isolation time was on average fourteen days, self-isolation meant that for at least sixty days (the regulated period of the state of emergency) the conduct of daily life took place largely in the personal home. Emergency is a situation of daily disturbance, and these drastic measures that humans had to adopt have generated a social impact on their ordinary life, influencing its quality. If in the case of the quarantine we discussed emergency housing, in the case of self-isolation we will discuss housing in emergency.

In an interview about "how we build at home", the architect Iulia Stanciu stated that "probably the first lesson of an architecture that works in terms of quality of living is about a sensitive and careful understanding of places, of situations, because if it comes to living, we live in all the situations of our lives." (2020). But how do we live in an emergency? 
arhitectura răspunde unor situații incerte astfel încât să mențină standardele calității vieții locuitorilor săi?

Pe lângă caracteristicile spațiale legate de suprafețele locuinței, dotări, amenajări sau context urbanistic, locuirea presupune activități cotidiene, interacțiuni sociale sau problematici legate de identitar. În contextul stării de urgență, tot ceea ce ține de viața socială a majorității populației, sau cel puțin a populației care a respectat măsurile prevăzute prin autoizolare, s-a mutat temporar în interiorul locuinței personale. Cercetarea de față își propune să descopere în ce măsură a reușit aceasta să răspundă noilor nevoi ale utilizatorilor săi, cum sa adaptat noilor cerințe funcționale date de internalizarea unor activități specifice, dar mai cu seamă ce impact a avut izolarea asupra condițiilor de viață.

Pentru a putea răspunde acestor întrebări, am realizat un studiu sociologic specific, cu caracter mai degrabă informativ. Culegerea datelor s-a realizat pe bază de chestionar individual distribuit prin intermediul platformelor de socializare din mediul online. Faptul că respondenții acestui chestionar au fost doar cei care au avut acces la internet și printro împrejurare sau alta au avut acces la chestionar în mod aleatoriu constituie una dintre limitările pe care ni le asumăm în acest studiu. Concluziile sunt limitate și pot fi subiective sau având o relevanță mică raportate la nivelul întregii societăți, însă pot constitui un punct de pornire al unei cercetări mult mai complexe.

Pe perioada stării de urgență, chiar dacă marea majoritate a locuitorilor s-a autoizolat la domiciliu, viața cotidiană și-a urmat cursul. Conform
How can architecture respond to uncertain situations so as to maintain the standards of quality of life of its inhabitants?

In addition to spatial characteristics related to the housing surfaces, facilities, home improvements or urban context, housing involves daily activities, social interactions or issues related to identity. In the context of the state of emergency, everything related to the social life of the majority of the population, or at least of the population that complied with the measures provided by selfisolation, has temporarily moved inside the personal home. The present research aims to discover to what extent the home has managed to meet the new needs of its users, how it has adapted to the new functional requirements given by the internalization of specific activities, but especially on the kind of impact the isolation had on living conditions.

In order to answer these questions, we conducted a sociological study with a simple random sampling model. The data collection was based on an individual questionnaire distributed through online social networking platforms. The fact that the people who responded to this questionnaire were the ones who had access to internet or by one way or another had random access to the questionnaire is definitely one of the limitations of this study. The conclusions are limited and can even be seen as subjective or with little relevance for the whole society, but they can definitely be a starting point of an even more complex research study.

During the state of emergency daily life followed its course even if the vast majority of the residents isolated themselves at home. According to the 
răspunsurilor primite prin intermediul chestionarului, 65.9\% dintre respondenți au ales să își desfășoare activitatea profesională sau academică și o parte din activitățile uzuale (precum cele sportive sau cele aferente petrecerii timpului liber sau pasiunilor) în interiorul locuinței personale. În prima parte, studiul a dorit să descopere unde șiau continuat oamenii activitățile respective și ce încăperi ale locuinței au preluat noile funcțiuni (fig. 3). Întrebările s-au axat pe locul de desfășurare al profesiei/ocupației, al hobby-urilor, pasiunilor și al activităților sportive, dar mai cu seamă pe calitatea acestor activități și pe felul în care s-au simțit oamenii practicându-le în locuința personală. În cea de-a doua parte a studiului, am dorit să înțelegem ce presupune din punct de vedere social locuirea în urgență și în ce măsură s-a schimbat rutina și stilul de viață al fiecăruia.

În opinia antropologului Vintilă Mihăilescu, „casa este privită ca o experiență socială a locuirii, a domesticirii și a dialogului reciproc definitoriu cu obiectele și spațiul înconjurător" (2009: 19). lar când acesta pune în discuție funcțiile sociale ale încăperii locuinței și transformarea acestora după căderea comunismului, spune despre camera de zi sau living că „regrupează din ce în ce mai mult familia, invitații, și de aceea se pune problema reamenajării conform noilor sale funcții." (Mihăilescu, 2009: 38).

Criza influențează experiența socială a locuirii. În contextul autoizolării, tot camera de zi este cea predominant aleasă de locuitori pentru a aduna membrii familiei și pentru a prelua noile funcțiuni. 0 posibilă explicație pentru această alegere ar fi generozitatea spațiului livingului (este de cele mai multe ori încăperea cu cea mai mare suprafață answers received through the questionnaire, 65.9\% of the respondents chose to carry out their professional or academic activity and part of the usual activities (such as sports, leisure or hobbies) inside their personal home. In the first part of the study, we wanted to find out the place where people continued their activities and which rooms of the house took over the new functions (fig. 3). The questions were focused on the places where the profession/occupation, hobbies, passions and sports activities took place, but especially on the quality of these activities and on the way people felt practicing them in their personal home. In the second part of the study, we wanted to understand what does housing in emergency mean from a social point of view and to what extent everyone's routine and lifestyle have changed.

In the view of anthropologist Vintilă Mihăilescu, "the house is seen as a social experience of living, domestication and mutually defining dialogue with its objects and the surrounding space" (2009: 19). And when he discusses the social functions of the house rooms and their transformation after the fall of communism, he states that the living room "increasingly brings together the family, guests, and therefore raises the issue of redevelopment according to its new functions." (Mihăilescu, 2009: 38).

The crisis is influencing the social experience of living. In the context of self-isolation, the living room is the one predominantly chosen by the residents to gather family members and take over the new functions. A possible explanation for this choice would be the generosity of the living room space (it is often the room with the largest area in 


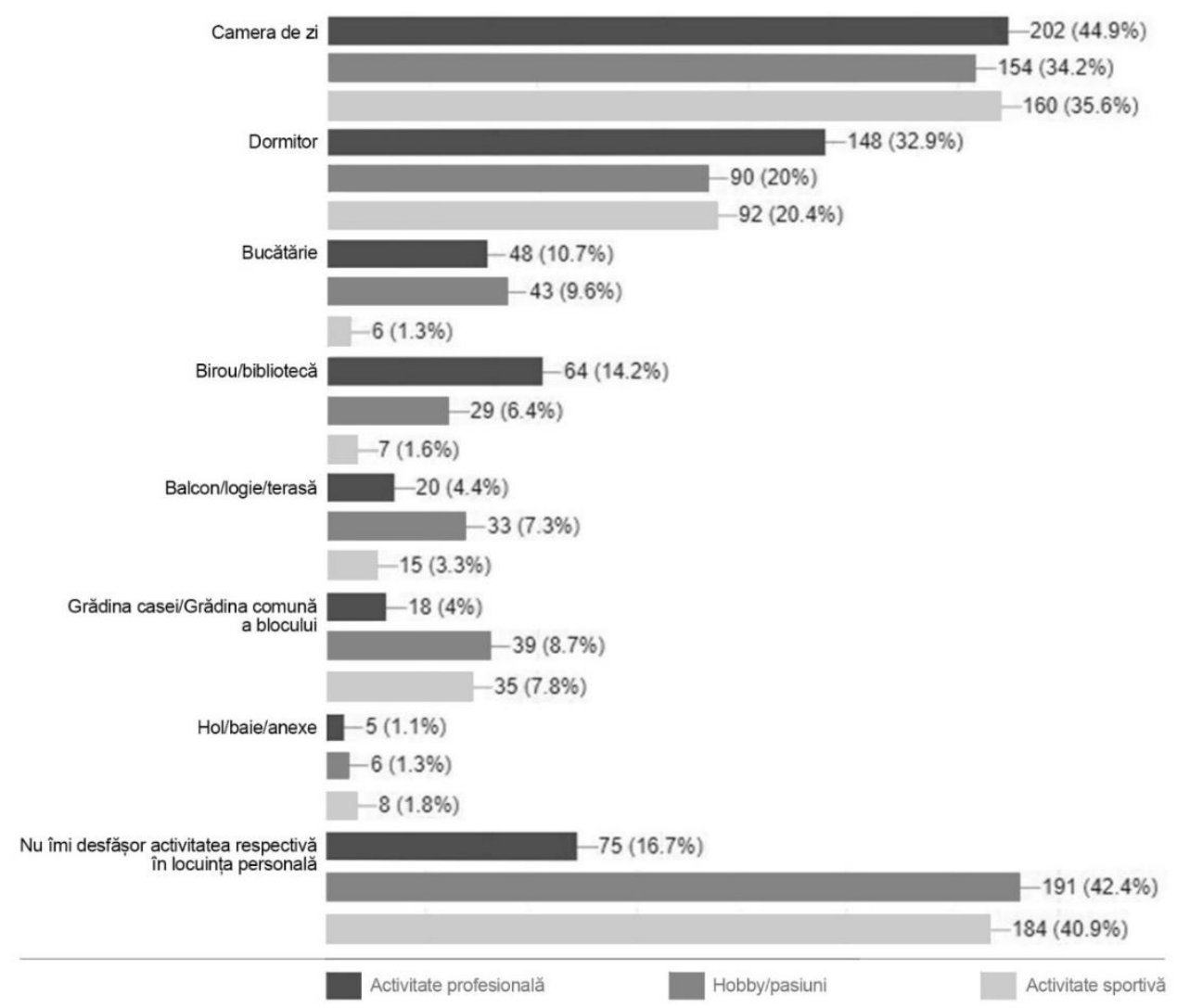

Fig. 3. Grafic cu situația răspunsurilor la întrebările legate de ce încăpere a locuinței personale a devenit locul de desfășurare a activității profesionale/academice, hobby-uri/pasiuni sau activități sportive pe perioada stării de urgență. Sursa: autorii (după informații extrase din chestionarul sociologic și prelucrate în SPSS de soc. Dana Gabriela Gîta)/

Graph with The answers to the questions related to which room of the personal housing became the place for professional / academic activity, hobbies / passions or sports activities during the state of emergency. Source: authors (after information extracted from the sociological questionnaire and processed in SPSS by soc. Dana Gabriela Gîta)

dintr-o locuință - minim 18mp., în timp ce dormitorul trebuie să aibă minim $12 \mathrm{mp}$. conform Legii Locuinței nr. 114/1996) care permite a house- minimum 18sqm, while the bedroom must have at least 12 sqm according to Housing Law No. 114/1996) which allows adjustment to different 
adaptarea la diferitele activități. Mai mult decât atât, abordările arhitecturale contemporane (și nu numai) presupun o amenajare interioară cât mai flexibilă a camerei de zi, fapt care permite reorganizarea acesteia și a obiectelor de mobilier în functie de nevoile actuale: „Camera de zi - nu mai este un spațiu de trecere, repoziționarea mobilierului a avut în vedere crearea unui cadru pe care îl identific ca fiind «locul de relaxare» în care petrecem după-masa împreună. Activitățile de zi cu zi le-am transferat în zona de living.”; „Datorită dimensiunilor mari ale camerei de zi și a faptului că are deschidere mare spre terasă, mi-a fost foarte util pentru a face sport, pentru a poza ce gătesc și pentru a lucra în liniște" (răspunsuri libere primite prin chestionarul sociologic).

Deși camera de zi și dormitorul sunt cele care au preluat în mare parte noile funcțiuni venite din exteriorul locuinței (biroul, sala de sport, atelierul de pictură etc.), din experiența respondenților reiese faptul că au existat și transferuri de funcțiuni sau utilizări interioare cotidiene între cele două: „Dormitorul - înainte de starea de urgență, 70\% din timpul petrecut acasă era în dormitor (I-am considerat ca fiind camera de refugiu, un loc potrivit pentru lectură, documentație). În situația actuală, dormitorul este doar pentru dormit. Activitățile de zi cu zi le-am transferat în zona de living" (răspuns liber primit prin chestionarul sociologic).

\section{Aprecierea spațiului încăperilor locuinței personale}

Așadar, aprecierea spațiului încăperii a depins într-o mare măsură de ce anume a presupus tipul de activitate desfășurat. Spre exemplu, se observă că în activities. Moreover, contemporary (and not only) architectural approaches require a more flexible interior design of the living room, which allows it and the furniture to be reorganized according to current needs: "The living room - is no longer a passageway, the repositioning of the furniture envisages the creation of a frame that I can identify as a 'place of relaxation ' in which we spend the afternoon together. I transferred my daily activities in the living room"; "Due to the large size of the living room and the fact that it has a large opening to the terrace, it was very useful for me to do sports, to take pictures of what I cook and to work in peace" (free answers received through the sociological questionnaire).

Although the living room and the bedroom are the ones that mostly took over the new functions coming from outside of the house (office, gym, painting workshop, etc.), from the experience of the respondents it appears that there were also transfers of functions or daily internal uses between the two rooms: "The bedroom - before the emergency $70 \%$ of the time spent at home was in the bedroom (I considered it as a refuge room, a suitable place for reading and documentation). In the current situation, the bedroom is only for sleeping. I transferred my daily activities to the living room area" (free response to the sociological questionnaire).

Appreciation of the space of the rooms in the house

Therefore, the appreciation of the space of the room depended to a large extent on what the type of activity carried out presumed. For example, it is 
cazul activităților sportive, cele care depind de un spațiu generos care să permită mișcările libere ale corpului, respondenții nu au fost atât de satisfăcuți de camera respectivă. Printre factorii care au influențat această apreciere se pot găsi limitările spațiale, suprafețele mici ale camerelor sau aglomerarea amenajării interioare. În timp ce unii respondenți reușesc să maximizeze spațiile de care dispun, afirmând că „împart aceeași cameră pe mai multe funcțiuni, zona de lucru, zona de dormit, zona de sport, chiar dacă dormitorul meu are $16 \mathrm{mp} . "$, alții spun că în timpul stării de urgență „activități sportive/hobby-uri au fost anulate din cauza crizei și pentru că spațiul locuinței nu permite realizarea acestora în interiorul locuintei."

Cu toate acestea, activitățile practicate fie s-au adaptat la caracteristicile spațiale ale încăperilor respective (suprafață, dotări, design și amenajare interioară), fie le-au modelat: „am reorganizat un dormitor în birou și se intercalează uneori treburile casnice cu programul de muncă”; „activitățile au avut o influență asupra locuinței: s-a extins masa din sufragerie devenind și birou, colțul camerei găzduiește un pupitru cu partituri, iar centrul aceleiași încăperi e liber, ca atunci când fac exerciții fizice să îmi pun izoprenul."

Atunci când au fost întrebați dacă au realizat modificări în locuința personală pentru a o putea adapta noilor cerințe funcționale, din totalul respondenților, un procent de $43 \%$ dintre aceștia au făcut acest lucru, în timp ce 57\% nu au intervenit asupra amenajării locuinței. Dintre modificările făcute, procentul cel mai ridicat (36\%) I-a avut modificarea locului unor obiecte din încăperi, urmat de înlocuirea sau adăugarea unor obiecte de mobilier (16.7\%), în timp ce un procent foarte mic observed that in the case of sports activities, those that depend on a generous space that allows free body movements, the respondents were not so satisfied with the room. Among the factors that influenced this appreciation, spatial limitations, the small surfaces of the rooms or the agglomeration of the interior design can be found. While some respondents manage to maximize the spaces they have, stating that "I share the same room on several functions, work area, sleeping area, sports area, even if my bedroom is 16 sqm.", Others say that during state of emergency "sports activities/hobbies were cancelled due to the crisis and because the living space does not allow them to be carried out inside the home."

However, the activities carried out either adapted to the spatial characteristics of the respective rooms (surface, facilities, design and interior design), or shaped them: "we reorganized a bedroom in the office and sometimes household chores are interspersed with work schedule"; "the activities had an influence on the house: the table in the living room was extended into an office, the corner of the room houses a desk with music sheets, and the centre of the same room is free, so that when I exercise I put on my isoprene."

When asked if they made changes to their personal home in order to adapt it to the new functional requirements, out of the total respondents, $43 \%$ of them did so, while $57 \%$ did not intervene in the arrangement of the home. Of the changes made, the highest percentage (36\%) was attributed to the change of location of some objects in the rooms, followed by the replacement or addition of furniture $(16.7 \%)$, while a very small percentage of respondents (5.6\%) achieved interior design works 
de respondenți (5.6\%) au realizat lucrări de amenajări interioare în locuința personală. Acolo unde a fost posibil, locuitorii au făcut schimbări în interiorul locuinței pentru a-și îmbunătăți condițiile de viață, însă un aspect pe care majoritatea celor chestionați l-au menționat a fost intervenția asupra spațiului exterior al casei (balconul, terasa sau grădina). Din nevoia interacțiunii cu lumea exterioară, respondenții fie au început să folosească mai frecvent acest spațiu, unii reamenajându-l: „un mare plus, avem o grădină mică a blocului, o curte interioară, care a devenit o oază de liniște a zilei" sau „am dorit să replicăm pe balcon atmosfera terasei localului favorit pe care îl frecventam înainte de debutul pandemiei", fie au constatat importanța majoră a acestuia prin lipsa lui: „un element al arhitecturii apartamentului care a devenit foarte important este lipsa geamurilor clasice sau a balconului, însemnând că nu există contact vizual cu afară" sau „cel mai mult îmi lipsește spațiul exterior și activitățile în aer liber pentru că locuiesc într-un apartament cu balcon închis" (răspunsuri libere primite prin chestionarul sociologic).

Pe lângă schimbările ce țin de obiectele de mobilier sau finisajele din locuință, curățenia a fost și ea abordată mai des pe perioada autoizolării. Un procent de 61.9\% dintre respondenți au afirmat că pe perioada stării de urgență au acordat mai multă atenție întreținerii curățeniei și a ordinii în locuința personală decât înaintea acesteia. Antropologul Adam Drazin afirma că „activitatea fizică, periodică, de renovare și curățare a locuinței presupun de asemenea o regenerare personală și socială" (2009: 84) și că „rearanjarea mobilei exprimă și reflectă stări interioare ale individului." (2009: 84). Putem afirma că nevoia de schimbare sau de ordonare a locuinței personale a venit în mare parte ca răspuns in the personal home. Where possible, residents made changes to the interior of the house to improve their living conditions, but one aspect that most respondents mentioned was the intervention on the outside space of the house (balcony, terrace or garden). Due to the need to interact with the outside world, respondents have either started to use this space more frequently, with some redesigning it: "a big plus is that we have a small block garden, an inner courtyard, which has become an oasis of peace for the day" or "we wanted to replicate on the balcony the atmosphere of the terrace of the favourite place we frequented before the pandemic", or noted its major importance due to the lack of it: "an element of the architecture of the apartment that has become very important is the lack of classic windows or balcony, meaning that there is no visual contact with the outside" or "I miss the outdoor space and outdoor activities the most because I live in an apartment with an enclosed balcony "(free answers received through the sociological questionnaire).

In addition to changes in furniture or home refinements, cleanliness has also been addressed more often during self-insolation. A percentage of $61.9 \%$ of the respondents stated that during the state of emergency they paid more attention to the maintenance of cleanliness and order in their personal home than usual. Anthropologist Adam Drazin stated that "periodic physical renovation and cleaning of the home also involves personal and social regeneration" (2009: 84) and that "rearrangement of furniture expresses and reflects the inner state of the individual." (2009: 84). We can say that the need to change or tidy up one's personal home came largely in response to the need to adapt 
la nevoia de adaptare la noile cerințe funcționale, însă ea poate fi și o manifestare a unor stări interioare prin care a trecut omul în criza pandemiei. Unul dintre respondenți afirma prin răspunsurile libere la chestionarul sociologic că „am mai mult timp pentru mine și pentru gospodărie. Petrec mai mult timp cu animalele de companie, întrețin grădina. Acest lucru l-am regăsit în momentul în care am încetat să mai fac activități cu importanță redusă, în afara gospodăriei."

Pe lângă curățenia efectivă a casei, majoritatea respondenților au menționat atenția sporită pentru igiena personală în perioada stării de urgență. Prin urmare, această nevoie de dezinfectare a locuinței, cât și a locuitorilor repune în discuție utilitatea spațiilor intermediare sau a unor încăperi precum holul. Astfel de spații intermediare pot fi cele care să aibă un rol medical. Prin urmare, holul poate $\mathrm{fi}$ considerat un spațiu de decontaminare: spațiul care mediază exteriorul (spațiul pandemiei) cu interiorul (spațiul de izolare). În amenajarea interioară contemporană a locuințelor, de cele mai multe ori holul este eliminat, accesul în casă făcându-se direct în zona camerei de zi, iar pe timpul pandemiei acest aspect face ca decontaminarea să fie făcută ori în exteriorul casei, ori în zona scării de bloc, dacă discutăm despre apartamente sau garsoniere.

Personalizarea spațiului este o caracteristică principală a procesului locativ. Prin urmare schimbându-se modul de locuire și adăugându-se toate aceste noi activități, în unele cazuri s-a schimbat amenajarea interioară a locuinței sau s-a schimbat ordinea obiectelor prin curățenie. Dar aceste schimbări sunt posibile doar în locuirea în urgență, acolo unde se poate interveni asupra to the new functional requirements, but it can also be a manifestation of some inner states that man went through in the pandemic crisis. One of the respondents stated through the free answers to the sociological questionnaire that "I have more time for myself and for the household. I spend more time with my pets and I maintain the garden. I regained this when I stopped doing minor activities outside the household."

In addition to the actual cleanliness of the house, most respondents mentioned increased attention to personal hygiene during the emergency. Therefore, this need to disinfect the home as well as the inhabitants calls into question the usefulness of intermediate spaces or rooms such as the hallway. Such intermediate spaces may be those that have a medical role. Therefore, the hall can be considered a decontamination space: the space that mediates the outside (pandemic space) with the inside (isolation space). In the contemporary interior design of homes, most often the hallway is removed, access to the house is made directly in the living room area, and during the pandemic this aspect makes decontamination to be done either outside the house or in the stairwell area of the apartment building, if we are talking about apartments or studios.

The personalization of the space is a main feature of the housing process. Therefore, changing the way of living and adding all these new activities, in some cases the interior design of the house has been changed or, by cleaning, the order of the objects has been changed. But these changes are possible only in the case of housing in emergency, where it is possible to intervene on the space. In emergency 
spațiului. În locuirea de urgență într-un spațiu impus, așa cum a fost cazul centrului de carantină discutat anterior, intervențiile asupra amenajărilor interioare sau personalizarea spațiului sunt fie inexistente, fie condiționate sau chiar interzise prin relația cu administrația responsabilă de cel carantinat și de spațiul pus la dispoziție acestuia. În autoizolare, relația cu administrația nu este prezentă, ci ține mai mult de gradul de responsabilitate al fiecăruia.

Starea de urgență datorată pandemiei a introdus un dezechilibru în viața cotidiană a fiecăruia. Arhitectul Dragoș Dascălu spunea că „introducerea dezechilibrului creează o stare percepută de vulnerabilitate a individului" (2016: 186) și că „arhitectura este o practică a dezechilibrului. Prin arhitectură este înlocuită o ordine naturală, preexistentă, cu una nouă artificială." (2016: 186) Însă în acest caz particular al locuirii în urgență, este posibil ca prin arhitectură, prin amenajare interioară sau doar prin ordine și curățenie, să fie reintrodus echilibrul. Așadar, prin aceste mici modificări sau personalizări ale spațiului personal, omul încearcă să își restabilească echilibrul și să își redefinească senzația de siguranță și ocrotire.

\section{Aprecierea desfășurării noilor activități în locuința personală}

Unul dintre respondenții chestionarului remarca faptul că „Acasă nu este locul potrivit pentru a-ți desfășura activitatea profesională, acasă este locul pe care noi îl percepem ca fiind un spațiu intim, privat, confortabil, care foarte rar poate fi asociat cu randamentul și satisfacția pe care locul de muncă țiI oferă." Într-adevăr, locuirea în urgență a însemnat locuirea acasă, iar „acasă reprezintă individualul, housing, an imposed space, as was the case of the quarantine centre discussed above, interventions on interior design or personalization of the space are either non-existent, conditional or even prohibited by the relationship with the administration responsible for the quarantined individual and the space at their disposal. In self-isolation, the relationship with the administration is not present, but it is more related to the degree of responsibility of each individual.

The state of emergency due to the pandemic has introduced an imbalance in everyone's daily life. Architect Dragoș Dascălu said that "the introduction of imbalance creates a perceived state of vulnerability of the individual" (2016: 186) and that "architecture is a practice of imbalance. Architecture replaces a natural, pre-existing order with a new artificial one." (2016: 186) But in this particular case of emergency housing, it is possible for the balance to be reintroduced through architecture, interior design or only through order and cleanliness. Therefore, through these small changes or adaptations of the personal space, the person tries to restore their balance and to redefine the feeling of security and protection.

\section{Appreciation of housing activities}

One of the respondents of the questionnaire remarked that "Home is not the right place to carry out your professional activity, home is the place we perceive as an intimate, private, comfortable space, which can rarely be associated with performance and satisfaction that the job offers you." Indeed, housing in emergency meant living at home, and "home represents the individual, the unique - or for 
unicul - or despre unic nu poate exista o definiție generală." (Mihăilescu, 2020: 27). Tocmai de aceea răspunsurile primite prin chestionar oferă perspective atât de diferite, subiective și chiar contradictorii legate de percepția oamenilor asupra activităților desfășurate în locuința personală pe perioada stării de urgență.

Omul este o ființă socială care are nevoie constantă de contact social. Spre exemplu, deplasarea la locul de muncă și desfășurarea efectivă a profesiei sau meseriei asigură într-o oarecare măsură acea interacțiune socială necesară fiecăruia. Marea majoritate a respondenților au afirmat că au fost afectați sau influențați de reducerea contactelor cu colegii de muncă sau de întâlnirile cu prietenii sau familia. Acesta poate fi unul dintre motivele pentru care ilustrația percepției asupra încăperii ca loc de desfășurare a muncii/studiului să fie ușor negativă în comparație cu celelalte două.

Mai mult decât atât, „orice casă este (cu)prinsă întro vecinătate, cu care întreține o serie lungă de relații și schimburi definitorii" (Mihăilescu, 2020: 33). Locuirea presupune interacțiunea cu vecinii, iar vizitele între vecini sunt o formă de sociabilitate foarte prezentă în societatea noastră. Izolarea la domiciliu a presupus inclusiv întreruperea oricăror contacte cu persoane din afara gospodăriei. Prin chestionarul sociologic, respondenții au fost întrebați dacă înaintea stării de urgență obișnuiau să organizeze întâlniri sau să primească vizitele unor colegi, prieteni sau membrii ai familiei în locuința personală: $34 \%$ dintre aceștia primeau des sau foarte des vizite, 33\% din când în când, în timp ce $33 \%$ destul de rar sau niciodată. Importanța acestor interacțiuni sociale - vizitele musafirilor care au ajuns chiar să stea la baza principiilor de amenajare the unique there can be no general definition." (Mihăilescu, 2020: 27). That is why the answers received through the questionnaire offer such different, subjective and even contradictory perspectives related to people's perception of the activities carried out in their personal home during the state of emergency.

The human is a social being who needs constant social contact. For example, going to work and actually pursuing a profession or trade ensures to some extent that social interaction necessary for everyone. The vast majority of respondents stated that they were affected or influenced by reduced contact with co-workers or meetings with friends or family. This may be one of the reasons why the illustration of the perception of the room as a place of work/study is slightly negative compared to the other two.

Moreover, "any house is included in a neighbourhood, with which it maintains a long series of relationships and defining exchanges" (Mihăilescu, 2020: 33). Housing involves interaction with neighbours, and visits between neighbours are a form of sociability very present in our society. Isolation at home also meant the interruption of any contact with people outside the household. Through the sociological questionnaire, respondents were asked if before the emergency they used to organize meetings or receive visits from colleagues, friends or family members in their personal home: $34 \%$ of them received frequent or very frequent visits, 33\% from time to time, while $33 \%$ quite rarely or never. The importance of these social interactions - the visits of guests who have even become the basis of the principles of interior design in some cases - is 
interioară a locuinței în unele cazuri - este semnalizată prin următoarea mărturie a unui respondent „Îmi lipsesc foarte mult și vizitele prietenilor, care erau o regulă înainte de starea de urgență, mai ales că ne-am amenajat toată zona de zi și terasa ca să poată găzdui cât mai mulți prieteni și vizite.".

Pentru a compensa însă nevoia de sociabilitate, pe perioada stării de urgență o bună parte din vizitele respective s-au mutat în mediul virtual. Mai mult decât atât, tehnologiile contemporane și noile mijloace de comunicare online au făcut posibile întâlniri de afaceri, mese luate în familie și chiar desfășurarea orelor de curs online. Internetul „a schimbat însăși ideea de intimitate, laptopul permițând o intimitate de-localizată, nomadă: "acasă» este, se poate spune, acolo unde se află laptopul/mobilul." (Mihăilescu, 2020: 60). Prin răspunsurile primite în chestionarul sociologic aflăm că 52.8\% dintre respondenții au folosit des și foarte des platforme de socializare pentru a se întâlni virtual cu colegi, prieteni sau membrii ai familiei din afara locuinței personale, $28.4 \%$ din când în când, în timp ce $18.8 \%$ destul de rar sau niciodată.

\section{Rutina și stilul de viață}

„Rutina noastră zilnică, cu interacțiunile aproape constante cu ceilalți, conferă consistență și formă faptelor noastre. Viețile noastre sunt organizate în jurul reluării unor scheme similare de comportament de la o zi la alta." (Giddens, 2010: 124). După cum am putut observa, rutina a fost influențată de starea de urgență. Arhitectura este cadru de desfășurare a vieții cotidiene și a fost nevoită să medieze impactul social al crizei pandemiei. Arhitectura fie a fost proiectată astfel signalled by the following testimony of a respondent "I miss the visits of friends, which were a rule before the state of emergency, especially since we have arranged the whole living area and the terrace so that it can accommodate as many friends and visitors as possible."

However, in order to compensate for the need for sociability, during the state of emergency a good part of the respective visits moved to the virtual environment. Moreover, contemporary technologies and new means of online communication have made possible business meetings, family meals and even online classes. The Internet "has changed the very idea of intimacy, with the laptop allowing a de-localized, nomadic intimacy: 'home' is, so to speak, where the laptop/mobile is." (Mihăilescu, 2020: 60). Through the answers received in the sociological questionnaire we found that $52.8 \%$ of respondents often and very often used social platforms to meet virtually with colleagues, friends or family members outside their personal home, $28.4 \%$ from time to time, while $18.8 \%$ quite rarely or never.

\section{Routine and lifestyle}

"Our daily routine, with almost constant interactions with others, gives consistency and form to our actions. Our lives are organized around the resumption of similar patterns of behaviour from day to day." (Giddens, 2010: 124). As we could see, the routine was influenced by the state of emergency. Architecture is a framework for everyday life and has had to mediate the social impact of the pandemic crisis. The architecture has either been designed so that it can be easily 
încât să poată fi ocupată facil de noile cerințe funcționale, fie a fost adaptată sau modificată de către locuitorii săi. Flexibilitatea spațiului interior pare să fie una din calitățile cele mai apreciate de către respondenții chestionarului sociologic, pentru că ea a permis adaptarea cu ușurință la noile rutine.

Cu toate acestea, „o casă este o relație care se împlinește în spațiu și se desfășoară în timp" (Mihăilescu, 2020: 28). lar factorul cheie care este prezent în toate mărturiile respondenților și care pare să fi influențat aprecierea modului de locuire în urgență este timpul: „Rutina s-a schimbat din cauza muncii acasă. Am mai mult timp la dispoziție pentru activitățile preferate (citit, grădinărit, scris) care înainte de asta erau aproape absente din viața mea."; „lucrăm de acasă, copiii fac home-schooling, cu toate acestea avem mai mult timp să fim împreună, să luăm mesele principale împreună"; „Totul are o mai mare utilitate în casă, mesele sunt în familie zilnic, avem timp pentru hobby-uri și muncă pentru că nu mai pierdem timpul pe drum"; Timpul salvat o dată cu eliminarea deplasărilor este de cele mai multe ori apreciat și valorificat pentru a îmbunătăți locuirea și interacțiunile sociale între membrii familiei în interiorul casei. Cu toate acestea, pentru unii respondenți desfășurarea tuturor activităților uzuale în locuința personală și reducerea contactelor sociale exterioare are o influență negativă: „pur și simplu petrec mai mult timp în garsonieră și încep să o simt ca fiind sufocantă."; „Oricât de confortabilă, spațioasă și dragă ar fi o locuință, să stai atât de mut timp într-un singur loc poate deveni apăsător" (răspunsuri libere primite prin chestionarul sociologic). Observăm din nou aprecieri contradictorii ale locuirii în urgență. occupied by the new functional requirements, or has been adapted or modified by its inhabitants. The flexibility of the interior space seems to be one of the qualities most appreciated by the respondents of the sociological questionnaire, because it allowed them to easily adapt to the new routines.

However, "a house is a relationship that is fulfilled in space and unfolds in time" (Mihăilescu, 2020: 28). And the key factor that is present in all the testimonies of the respondents and that seems to have influenced the appreciation of the way of living in an emergency is the time: "The routine has changed due to working at home. I have more time available for pre-existing activities (reading, gardening, writing) which before this were almost absent from my life."; "We work from home, the children do home-schooling, however we have more time to be together, to have the main meals together"; "Everything is of great use in the house, meals are eaten with the family every day, we have time for hobbies and work because we do not waste time on the road"; The time saved with the elimination of travel is often appreciated and used to improve housing and social interactions between family members inside the house. However, for some respondents, carrying out all the usual activities in the personal home and reducing external social contacts has a negative influence: "I simply spend more time in the studio and start to feel suffocated."; "No matter how comfortable, spacious and dear a home may be, spending so much time in one place can be stressful" (free answers received through the sociological questionnaire). We note again contradictory assessments of housing in emergency. 
În analiza sa sociologică a vieții, Erving Goffman spunea că „,̂n studiul proceselor sociale este important să se descrie standardele decorului; (dar că) este foarte dificil să se facă acest lucru pentru că persoanele au tendința de a lua aceste standarde ca atare și să nu realizeze că au făcut acest lucru până nu are loc un accident, o criză sau o circumstanță ciudată." (1956: 68) Este posibil ca ipostaza de criză datorată pandemiei de coronaviroză să fi readus la lumină importanța legăturii dintre calitatea vieții și calitatea arhitecturală a locuinței.

John Cary, în studiile sale dedicate unei arhitecturi pentru demnitate, afirma că „Nimic nu influențează mai mult calitatea vieților noastre decât design-ul sau amenajarea locuințelor noastre, a școlilor, a locurilor de muncă sau a spațiului public. Cu toate acestea arhitectura este luată ca atare (taken for granted). Oamenii nu realizează că ei merită mai bine sau că mai bine este posibil." (2017: 18). Dar mai ales într-o situație cum este cea în cauză, în care în locuința personală se internalizează și se suprapun funcțiunile locuirii, învățământului, serviciului sau sportului. Așadar, după cum menționam anterior, criza sau dezechilibrul a făcut ca omul să își reconsidere relația cu locuința: „Pot să spun că în situația actuală, prin schimbările impuse de context, am început să simt spațiul apartamentului ca fiind acasă, nu doar locul unde vin să mă odihnesc ca a doua zi să pot merge iar la muncă" (răspuns liber primit prin chestionarul sociologic).

\section{Concluzii}

În primul rând, locuirea de urgență (carantina) și locuirea în urgență (izolarea la domiciliu) se diferențiază prin durată. Carantina a durat în medie paisprezece zile, în timp ce izolarea la domiciliu (cea
In his sociological analysis of life, Erving Goffman said that "in the study of social processes it is important to describe the standards of the setting; (but) it is very difficult to do this because people tend to take these standards as such and do not realize that they have done so until an accident, a crisis or a strange circumstance occurs." (1956: 68) It is possible that the crisis situation due to the coronavirus pandemic has brought to light the importance of the link between the quality of life and the architectural quality of housing.

John Cary, in his studies dedicated to architecture for dignity, stated that "Nothing influences the quality of our lives more than the design or arrangement of our homes, schools, workplaces or public space. However, the architecture is taken for granted. People don't realize that they deserve better or that better is possible." (2017: 18). But especially in a situation such as the one in question, in which the functions of housing, education, work or sport are internalized and overlapped in the personal home. So, as we mentioned before, the crisis or imbalance made the person reconsider their relationship with the house: "I can say that in the current situation, through the changes imposed by the context, I began to feel the apartment space as home, not just a space where I come to rest so I can go to work again the next day" (free answer received through the sociological questionnaire).

\section{Conclusions}

Firstly, emergency housing (quarantine) and housing in emergency (home isolation) are differentiated by duration. The quarantine lasted on average fourteen days, while the isolation at home (the one imposed 
impusă de autorități) a durat șaizeci de zile, cât timp a fost instaurată starea de urgență pe teritoriul României. Cu toate acestea, ieșirea din carantină a presupus intrarea în izolare la domiciliu. Așadar, din locuința de urgență, omul a trecut în locuința în urgență. Tocmai din acest motiv cea mai mare parte a studiului s-a concentrat pe analiza sociologică și arhitecturală a locuirii în urgență.

În al doilea rând, diferența majoră între locuirea de urgență în centrul de carantină și locuirea în urgență la domiciliu este cu siguranță relația omului cu administrația sau, generic, cu puterea statală. În centrul de carantină, această relație este de control și de subordonare și are o influență majoră asupra vieții utilizatorului pentru că statul este cel responsabil de asigurarea condițiilor de viață ale omului și de protejarea sănătății populației. În izolarea la domiciliu, responsabilitatea se transferă de la autorități la populație, omul fiind cel care se îngrijește de propriile condiții de viață, de menținerea (sau nu) a anumitor standarde sociale și de continuarea activităților uzuale, fiind totodată cel responsabil de protejarea în fața riscurilor infectării. În ambele situații însă prin locuire se încearcă restabilirea siguranței.

Ne întrebam la începutul studiului dacă arhitectura nu are un rol terapeutic și dacă, pe lângă dotările sanitare, locuirea nu este cea care poate primi funcțiuni medicale și care poate avea o influență majoră în restabilirea echilibrului în urma unei situații de tulburare a cotidianului. După cum am putut observa, în această situație de criză locuința a fost mai mult decât un adăpost. La exterior, ea a devenit o unealtă în limitarea răspândirii bolilor prin capacitatea de a izola locuitorii săi. La interior, prin calitățile arhitecturale sau prin amenajarea by the authorities) lasted sixty days, while the state of emergency was established on the Romanian territory. However, exiting quarantine meant entering isolation at home. So, from the emergency housing, the man moved into housing in emergency. Precisely for this reason most of the study focused on the sociological and architectural analysis of housing in emergency.

Secondly, the human relationship with the administration or, in general, with the state power is the major difference between emergency housing in the quarantine centre and housing in emergency at home. In the quarantine centre, this relationship is of control and subordination and has a major influence on the user's life because the state is responsible for ensuring human living conditions and protecting the health of the population. In isolation at home, the responsibility is transferred from the authorities to the population, the person being the one who takes care of their own living conditions, maintaining (or not) certain social standards and continuing the usual activities, being also responsible for their protection against risks of infection. In both cases housing is an attempt to restore security.

We wondered at the beginning of the study if architecture does have a therapeutic role and if, in addition to health facilities, the house is the one that can receive medical functions and can have a major influence in restoring balance following a situation of daily disorder. As we could see, in this crisis situation the house was more than a shelter. On the outside, it has become a tool in limiting the spread of disease through its ability to isolate its inhabitants. On the inside, through the architectural qualities or the interior design of the spaces, it was 
interioară a spațiilor a putut media impactul social al crizei, marcat de incertitudine și vulnerabilitate.

În izolare la domiciliu, spațiul este familiar, personal și personalizabil, identitar, este acel acasă dificil de descris în mod obiectiv. Capacitatea de personalizare a spațiului a facilitat adaptarea locuinței la noile cerințe funcționale date de internalizarea activităților precum studiu, educație, desfășurarea activității profesionale, practicarea activităților sportive sau a hobby-urilor. Prin comparație, în centrul de carantină spațiul este străin, neutru sau auster, personalizarea spațiului fiind extrem de limitată sau imposibilă. Prin urmare locuirea într-un spațiu impus este mult condiționată față de locuirea într-un spațiu ales, însă putem spune că acest fapt este compensat prin durată.

Mai mult decât atât, în carantină de cele mai multe ori dotările au fost minimale și au acoperit strictul necesar al supraviețuirii sau al tratamentului (acolo unde a fost cazul). În izolare la domiciliu, în funcție de posibilitățile fiecărei gospodării, dotările au acoperit, de cele mai multe ori, mai mult decât strictul necesar. Deși locuirea de urgență reductibilă la minimal este posibilă, ea a fost acceptată datorită reglementării prin lege a carantinării instituționalizate în spații impuse. În locuirea în urgență însă, am constatat faptul că marea majoritate a oamenilor nu conștientizează importanța design-ului care asigură un anumit confort sau standard de viață, precum și capacitatea lui umanizatoare decât în momentul introducerii dezechilibrului. Pentru a-și restabili echilibrul, oamenii au apreciat spațiul care a putut fi ușor adaptabil sau care a putut fi reamenajat pentru a satisface noile cerințe. Locuitorii au scos la iveală importanța spațiilor intermediare ale locuinței care able to mediate the social impact of the crisis, which was marked by uncertainty and vulnerability.

In isolation at home, the space is familiar, personal and adaptable, an identity, it is that home that is difficult to describe objectively. The ability to customize the space facilitated the adaptation of the home to the new functional requirements given by the internalization of activities such as study, education, professional activity, practicing sports or hobbies. By comparison, in the quarantine centre the space is foreign, neutral or austere, the customization of the space being extremely limited or impossible. Therefore, living in an imposed space is much more conditioned than living in a chosen space, but we can say that this is compensated by the duration.

Moreover, in quarantine most of the endowments were minimal and covered the bare necessities of survival or treatment (where appropriate). In isolation at home, depending on the possibilities of each household, the facilities covered, most of the time, more than strictly necessary. Although emergency housing reduced to a minimum is possible, it has been accepted due to the regulation by law of institutionalized quarantine in imposed spaces. However, we found that in housing in emergency the vast majority of people are not aware of the importance of design that ensures a certain comfort or standard of living, as well as its humanizing capacity until the introduction of imbalance. In order to restore their balance, people appreciated the space that could be easily adapted or that could be redesigned to meet the new requirements. Residents revealed the importance of the intermediate spaces of the house that can take over the medical functions (the hallway as a space of 
pot prelua funcțiuni medicale (holul ca spațiu de decontaminare), precum și importanța spațiilor exterioare (logie, balcon, terasă sau grădină) care în situația izolării pot deveni spațiile de contact cu lumea exterioară sau cu natura.

Pe termen scurt, viața cotidiană a fost afectată și s-a transformat, iar locuința fie s-a adaptat, fie a fost adaptată, datorită măsurilor impuse prin starea de urgență, însă nu putem ști (încă) care vor fi implicațiile pe termen lung (dacă o dată cu ridicarea stării de urgență oamenii vor reveni sau nu întocmai la rutina sau stilul de viață pre-pandemie). Cu toate acestea, am putut ilustra faptul că impactul unei situații de criză poate fi mediat prin arhitectură. Din acest considerent, putem afirma că este nevoie ca în proiectare să fie luată în considerare în prealabil posibila apariție a urgenței și că este nevoie ca locuinței să i se permită capacitatea de adaptare la necunoscut și de evoluție prin preluarea de noi funcțiuni (în cazul de față cele medicale). decontamination) and the importance of outdoor space (loggia, balcony, terrace or garden) which in the isolation can become spaces of contact with the outside world or with nature.

In the short term, everyday life has been affected and transformed, and housing has either adapted or been adapted due to the measures imposed by the state of emergency, but we cannot know (yet) what the long-term implications will be (if once with the lifting of the state of emergency people will or will not return exactly to the pre-pandemic routine or lifestyle). Nonetheless, we were able to illustrate that the impact of a crisis situation can be mediated through architecture. For this reason, we can say that in the design it is necessary to take into account in advance the possible occurrence of the emergency and that it is necessary to allow the home the ability to adapt to the unknown and to evolve by taking over new functions (in this case the medical ones).

\section{Referinţe/ References}

Asociația Dăruiește Viață, 2020, Comunicate de Presă, Spital modular pentru pacienții cu COVID-19, Proiecte, Disponibil online pe: https://www.daruiesteviata.ro/proiecte/spital-modular-pentru-pacientii-cu-covid-19/EPMrPK7Bp

Cassar, P. (1987). A Tour of the Lazzaretto Buildings. În Melita Historica, Volumul 9, nr. 4, (p. 369). Valeta: Editura Societatea Melita Historica

Cary, J. (2017). Design for good: A new era of architecture for everyone (p. 18). Washington: Island Press.

Dascălu, D. (2016). Arhitecturi relaționale (p. 186). Iași: Editura Lumen.

Drazin, A. (2009). Vânătoarea de molii: curățenie, intimitate și progres în România, în Mihăilescu, V. (coord.), Etnografii urbane: cotidianul văzut de aproape (p. 84). București: Editura Polirom.

Instituția Prefectului Județului Cluj, Comunicate de Presă, 2020, Disponibil online pe:

https://cj.prefectura.mai.gov.ro/comunicat-de-presa-unitate-suport-tratare-covid-19-sala-polivalenta-bt-arena/ 
Ivanov, B. (2020). Arhiepiscopia Clujului oferă hrană persoanelor aflate în autoizolare și pune la dispoziție spații de carantină în Mitropolia Clujului. Disponibil online pe: https://www.mitropolia-clujului.ro/arhiepiscopia-clujuluiofera-hrana-persoanelor-aflate-in-autoizolare-si-pune-la-dispozitie-spatii-de-carantina/

Giddens, A. (2010). Sociologie, Ediția a V-a (p. 124). București: Editura ALL.

Goffman, E. (1956). The presentation of Self in Everyday Life, Monograph. No. 2 (p. 68) Edinburgh: Editura Univeristy of Edinburgh Social Sciences Research Centre.

Manaugh, G., Budds, D. (17.03.2020) Design in the age of pandemics, în Curbed. Disponibil online pe: https://wwwcurbed-com.cdn.ampproject.org/c/s/www.curbed.com/platform/amp/2020/3/17/21178962/design-pandemicscoronavirus-quarantine

Mihăilescu, V. (2020). Acasă în lume, în Mihăilescu, V., Tudora, I. în colab. cu Bădescu, G., Bălășescu, A., Grecu, M., Acasă în lume (p. 27,28,33,60) București: Editura Igloo Media.

Mihăilescu, V. (2019). Antropotectură. Zidul și pârleazul. O perspectivă antropologică, în Roibu-Movilă, A., Drișcu, M., Cozma, L. (coord.), Arhitectura celuilalt: tineri cu gânduri către lume (p. 27) București: Editura Fundației Arhitext Design.

Mihăilescu, V. (2009). Introducere, în Mihăilescu, V. (coord.), Etnografii urbane: cotidianul văzut de aproape (p. 19). București: Editura Polirom.

Mihăilescu, V. (2009). Blocul între loc și locuire. Teme și probleme de etnologie urbană, în Mihăilescu, V. (coord.), Etnografii urbane: cotidianul văzut de aproape (p. 38) București: Editura Polirom.

Ministerul Apărării Naționale, Comunicate de Presă, 2020a, Disponibil online pe: https://www.mapn.ro/cpresa/16519_instalarea-unui-spital-modular-de-izolare-\%C8\%99i-tratament-laconstan\%C8\%9Ba

Ministerul Apărării Naționale, Comunicate de Presă, 2020b, Disponibil online pe: https://www.mapn.ro/cpresa/16512_ministerul-apararii-na\%C8\%9Bionale-instaleaza-forma\%C8\%9Biuneamedicala-de-nivel-rol-2-la-institutul-\%E2\%80\%9Eana-aslan\%E2\%80\%9D

Stanciu, I. (2020) Arh. Iulia Stanciu, STARH: Paradoxal, cred că a construi „acasă” pentru un arhitect este de a nu construi totul absolut și fără rest și de a lăsa loc casei și locuitorilor să evolueze. Disponibil online pe: https://www.borocommunication.ro/arh-iulia-stanciu-starh-paradoxal-cred-ca-a-construi-acasa-pentru-unarhitect-este-de-a-nu-construi-totul-absolut-si-fara-rest-si-de-a-lasa-loc-casei-si-locuitorilor-sa-evolueze/

***Decret nr. 195/16.03.2020 privind instituirea stării de urgență pe teritoriul României publicat în Monitorul Oficial nr. 212 din 16.03.2020, Disponibil online pe: http://legislatie.just.ro/Public/DetaliiDocument/223831

***Decret nr. 240/14.04.2020 privind prelungirea stării de urgență pe teritoriul României publicat în Monitorul Oficial nr. 311 din 14.04.2020, Disponibil online pe: http://www.just.ro/wp-content/uploads/2020/04/decretul-240-2020m-of-311-din-14-apr-2020.pdf

***Legea nr. 114/1996 Legea Locuinței, publicată în Monitorul Oficial nr. 393 din 31.12.1997, Disponibil online pe: http://www.cdep.ro/pls/legis/legis_pck.htp_act_text?idt=1614

***Ordinul nr. 313/26.02.2020 pentru instituirea măsurii de carantină a persoanelor în situația de urgență de sănătate publică internațională determinată de infectarea cu COVID-19 și stabilirea unor măsuri în vederea prevenirii și 
limitării efectelor epidemiei, Ministerul Sănătății, Disponibil online pe:

http://www.cnas.ro/casalba/post/type/local/ordin-nr-313-din-26-02-2020-covid-19.html

***Ordonanța de urgență nr. 11/2020 privind stocurile de urgență medicală, precum și unele măsuri aferente instituirii carantinei, publicată în Monitorul Oficial nr. 102 din 11.02.2020, Disponibil online pe:

https://lege5.ro/Gratuit/gm3danzxgi2q/ordonanta-de-urgenta-nr-11-2020-privind-stocurile-de-urgenta-medicalaprecum-si-unele-masuri-aferente-instituirii-carantinei

***Ordonanța militară nr. 1/17.03.2020 privind unele măsuri de primă urgență care privesc aglomerările de persoane și circulația transfrontalieră a unor bunuri, publicată în Monitorul Oficial nr. 219 din 18.03.2020, Disponibil online pe: http://legislatie.just.ro/Public/DetaliiDocument/223888 